\title{
SOLAR TECHNOLOGY CENTER
}

April 27, 2011

Funded by the U.S. Department of Energy Solar Technologies Program

DE-FG36-05G085031

Award Recipient:

UNLV RESEARCH FOUNDATION

8311 W. Sunset Road, Suite 200

Las Vegas, NV 89113

702-895-2833

loni.benard@unlv.edu 


\section{Final Report}

Project Title: $\quad$ Solar Technology Center

Project Period: $\quad$ August 1, 2005 to January 31, 2011

Date of Report: $\quad$ April 27, 2011

Recipient: $\quad$ UNLV Research Foundation

Award Number: $\quad$ DE-FG36-05G085031

Working Partner: $\quad$ University of Nevada, Las Vegas (UNLV)

Cost-Sharing Partners: City of Boulder City, Nevada

DOE Manager: $\quad$ Steven D. Palmeri, DOE-GO Project Manager

Collaborators: University of Nevada, Las Vegas

Technical Contact: Dr. Robert Boehm

(702) 895-4160

bob.boehm@unlv.edu

Administrative Contact: Loni Benard

(702) 895-2833

loni.benard@unlv.edu

Principal Investigator: Dr. Robert Boehm

(702) 895-4160

bob.boehm@unlv.edu 


\section{DISCLAIMER}

This report was prepared as an account of work sponsored by an agency of the United States Government. Neither the United States Government nor any agency thereof, nor any of their employees, makes any warranty, express or implied, or assumes any legal liability or responsibility for the accuracy, completeness or usefulness of any information, apparatus, product, or process disclosed, or represents that its use would not infringe privately owned rights. Reference herein to any specific commercial product, process, or service by trade name, trademark, manufacturer, or otherwise does not necessarily constitute or imply its endorsement, recommendation, or favoring by the United States Government or any agency thereof. The views and opinions of authors expressed herein do not necessarily state or reflect those of the United States Government or any agency thereof.

\section{ACKNOWLEDGMENT}

This was prepared with the support of the U.S. Department of Energy (DOE), Golden Field Office, Grant number DE-FG36-05G085031. However, any opinions, findings, conclusions, or recommendations expressed herein are those of the author(s) and do not necessarily reflect the views of the DOE. 


\section{TABLE OF CONTENTS}

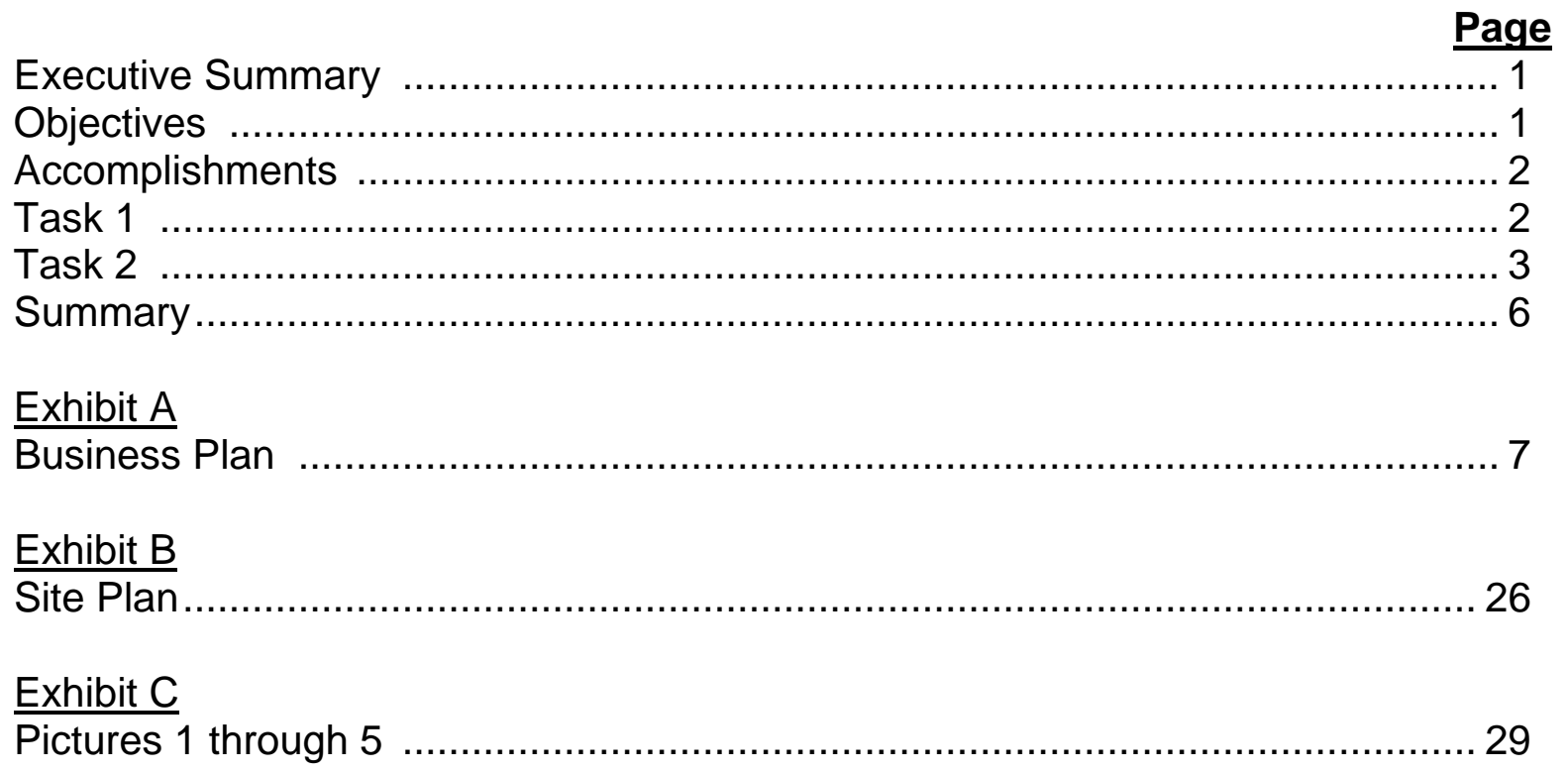




\subsection{EXECUTIVE SUMMARY}

The Department of Energy, Golden Field Office, awarded a grant to the UNLV Research Foundation (UNLVRF) on August 1, 2005 to develop a solar and renewable energy information center. The Solar Technology Center (STC) is to be developed in two phases, with Phase I consisting of all activities necessary to determine feasibility of the project, including design and engineering, identification of land access issues and permitting necessary to determine project viability without permanently disturbing the project site, and completion of a National Environmental Policy Act (NEPA) Environmental Assessment. Phase II is the installation of infrastructure and related structures, which leads to commencement of operations of the STC.

The STC is located in the Boulder City designated 3,000-acre Eldorado Valley Energy Zone, approximately 15 miles southwest of downtown Boulder City and fronting on Eldorado Valley Drive. The 33-acre vacant parcel has been leased to the Nevada Test Site Development Corporation (NTSDC) by Boulder City to accommodate a planned facility that will be synergistic with present and planned energy projects in the Zone. The parcel will be developed by the UNLVRF. The NTSDC is the economic development arm of the UNLVRF. UNLVRF will be the entity responsible for overseeing the lease and the development project to assure compliance with the lease stipulations established by Boulder City. The STC will be operated and maintained by University of Nevada, Las Vegas (UNLV) and its Center for Energy Research (UNLV-CER).

Land parcels in the Eldorado Valley Energy Zone near the 33-acre lease are committed to the construction and operation of an electrical grid connected solar energy production facility. Other projects supporting renewable and solar technologies have been developed within the energy zone, with several more developments in the horizon.

\subsection{OBJECTIVES}

The objective is to develop a publicly accessible facility to demonstrate and perform research on solar and other renewable energy technologies. The STC will also offer public information services to the community by educating students through hands-on experience, and by educating the general public. The STC will be open to anyone interested in the work being done at the center or renewable energy in general. The STC will also act as a clearinghouse and local resource for renewable energy and conservation information.

The completed project is expected to provide public exposure to real world solar and other renewable energy technologies operating in a high desert setting through its research, development, conservation, educational training, and outreach activities. 


\subsection{ACCOMPLISHMENTS}

\section{Task 1: Project Coordination and Oversight}

Task 1.1: Prepare project proposal with budget and schedule and coordinate with funding entity

A business plan was developed, edited and submitted to Boulder City. This plan will be used as a marketing tool for the Center and to encourage participation in securing continued funding. The plan includes development, as well as operational activities and projected schedules. A copy of the business plan is attached as Exhibit A.

Task 1.2: Coordinate with Boulder City to maintain the lease performance requirements

This task is on-going and will not be completed until the lease agreement has expired, currently on May 15, 2041.

The original lease was effective May 16, 2001 for 320 acres located within the Boulder City Solar Valley, at a lease payment of $\$ 1.00$ per year.

Amendment No. 01-697A, dated September 28, 2004, revised the 320 acres to 40 acres, located in the same valley at the same rate due to Boulder City determining this project would be a better fit on the 40-acre parcel. Amendment No. 01-697B, dated November 13, 2007, revised the 40 acres to the current 33 acres on November 13, 2007 due to a request by Solargenix who requested the 40 acres for future expansion. All parties agreed to the new 33-acre site.

Task 1.3: Coordinate with concerned Nevada entities to affirm project features and approach

UNLV-CER has communicated with several other departments at UNLV to determine whether opportunities exist for joint research projects. Meetings were held at the site to determine feasibility and everyone agreed it was a great site and would work perfectly. Unfortunately, none of the proposals were awarded to UNLV and the projects did not occur. UNLV-CER has also made other Nevada entities aware of the progress on this project in an effort to encourage use of the facility by high technology renewable energy businesses.

Task 1.4: Coordinate with other entities in the Energy Zone

Discussions were held with Acciona Solar Power and El Dorado Energy in the summer of 2007, by both the UNLVRF and UNLV-CER. UNLVRF drafted a Memorandum of Understanding (MOU) between Acciona and UNLVRF in July 2009 allowing Acciona to use the STC for solar experiments. The MOU expires in July 2012, but it can be extended by mutual agreement of parties. As part of the MOU, Acciona agreed to use and pay UNLV graduate students on their project. 
Task 1.5: Conduct competitive Architect and Engineering subcontract process

A competitively solicited engineering subcontract was awarded to CivilWorks, Inc. on March 26, 2008 to prepare the civil engineering drawings and the drainage plan for the site. Additional documentation was prepared to provide for the Southern Nevada Health District septic tank approvals. A copy of the site plan is attached under Exhibit B hereto.

In addition, a purchase order was awarded to Ninyo \& Moore to perform the percolation tests, required to obtain the septic tank approval. The final stamped test results were provided to UNLVRF on May 7, 2008.

Task 1.6: Oversight of selected Architect and Engineering performance

This was an ongoing process with the firm CivilWorks. Project meetings are held on an as-needed basis. The contract was completed on April 30, 2009.

Task 1.7: Track project schedule and budget report

Delays occurred due to the length of time it took to receive NEPA approval, and due to Boulder City approving plans and then revising them several times during construction. These delays did not result in additional construction costs. Updates were provided to DOE within the quarterly technical and cost reports.

Task 1.8: Explore and evaluate opportunities to develop an energy research component to be included in the STC and establish working relationships with other entities

Discussions have taken place with renewable energy firms in Southern Nevada as well as others throughout the US who may be interested in funding research and/or joint research opportunities. Acciona is one firm who signed an MOU. Discussions will continue and additional marketing activities will be pursued and other opportunities explored by UNLV-CER after grant completion.

\section{TASK 2: Project Development Work}

Task 2.1: Conduct survey and staking of 33-acre site

A purchase order was awarded to E.G. Radig to perform a topographic survey of the land in January 2008. This was required for CivilWorks, Inc. to prepare the site drawings.

Task 2.2: Perform all necessary land access activities

Work for this task is included in the site planning processes conducted through the architectural and engineering subcontractor. Land for development of the facility as well as ingress and egress are included in the site plan. Permits for access will be included in the permitting process for the facility. 


\section{Task 2.3: Conduct NEPA process}

A competitive award was made to Ninyo \& Moore who proposed using Mangi Environmental; a DOE approved National Environmental Protection Act (NEPA) contractor, and MBP Consulting. DOE approved Ninyo and Moore and the contract was awarded on April 14, 2008.

A Memorandum of Understanding was agreed to and signed by DOE, Ninyo \& Moore and UNLVRF, effective May 5, 2008.

The NEPA Environmental Assessment process was closely adhered to. Letters from resource agencies were reviewed and a discussion with U.S. Fish and Wildlife Services was conducted. The cultural resources records were searched and an Administrative Draft EA was submitted to the DOE for review. Comments were received from the DOE and responses were provided and final Assessment was submitted. The Environmental Assessment was approved with the Findings of No Significant Impact on January 13, 2009. However, after the FONSI was issued, the U.S. Fish and Wildlife Services requested another opportunity to review. A final letter was received from the U.S. Fish and Wildlife Services on May 15, 2009.

The NEPA was required prior to construction beginning. The modification to the grant allowing the UNLVRF to begin the construction process was received July 22, 2009.

Task 2.4: Design features of project necessary for initial operation

This task is included in the architectural and engineering subcontract in coordination with the UNLV-CER as the end user of the facility. Design features are included in the facility plan as well as the attached Business Plan.

Task 2.5: Identify and prepare applications for all needed permits

The State of Nevada requires a Tortoise Permit be issued prior to the disturbance of any land, at $\$ 550$ per acre. With a 33-acre site, this cost would be prohibitive to the project. Discussions were held with Boulder City, and it was agreed the fee would only be applied to land which would be disturbed. Discussions were held with the UNLV-CER, and it was agreed 5 acres would be utilized and fenced in at this time, at a total permit fee of $\$ 2,750$.

A Technical Drainage Study was submitted to Boulder City on July 22, 2008. The Clark County Regional Flood Control concurrence was submitted to Clark County on August 12, 2008 and approval was received on September 23, 2008.

Land Development Civil Plans were submitted to Boulder city on August 19, 2008.

Task 2.6: Determine availability and cost of utility services

Power - Discussions were held with Nevada Power (now NV Energy) in June 2008 to provide energy to the site. A letter was received stating the cost would be $\$ 3,259,682$. Since this amount exceeds our budget, a generator will be used until such time as renewable energy generators are installed on the site and the site functions off the grid. Boulder City One, a new firm attempting to 
locate to the East of our site, has agreed to provide power to the STC after they move the power lines down to their site. They agreed to provide the power at no cost to the STC for 2 years. Unfortunately, they have not started construction as of April 2011, but they are still hopeful to begin sometime in 2011. A used diesel generator was purchased to provide power to the STC until a permanent source can be secured.

Water - Water is available on El Dorado Valley Drive and the construction project included extending the water line to the STC.

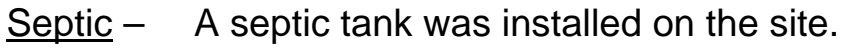

Phone - At this time, cellular phones will be used while at the site. A UNLV-CER number will be provided for the public to request information of the site, operating hours, etc.

Cable - $\quad$ At this time there are no plans to install cable. If after all work is completed and there are sufficient funds remaining, installing cable will be explored further.

Task 2.7: Support UNLVRF efforts to identify partnership opportunities with cost share potential

Discussions have taken place with various renewable energy companies as well as other UNLV academic departments to secure joint venture or partnership opportunities that will contribute to the center's self sufficiency. UNLV-CER continues to make the business and educational communities aware of this project and it's potential.

Task 2.8: Assemble complete project site design specifications and drawing package

A Business Plan was developed and submitted to Boulder City. The plan was updated and resubmitted to the City on August 24, 2008. The Land Development Civil Plans (wet-stamped civil engineering drawings) were also submitted on August 19, 2008.

Task 2.9: Identify potential EPC contractor for site preparation and construction of all project site features

In an effort to help us tighten up our budget, several local contractors were contacted to determine their interest in bidding for site preparation and project feature construction activities and to provide a rough estimate of cost for their specific areas of expertise.

Site Preparation - A competitive award process was used to secure a General Contractor to oversee the construction of the parking area, installation of the septic tank, water lines, and fence. Martin Harris Construction was the low bidder. A contract was awarded on January 21, 2010, with a notice to proceed of February 15, 2010 and a completion date of May 16, 2010. The actual construction completion date was July 31, 2010, due to Boulder City requested revisions to the waterline.

Modular Building - A competitive award was made to Pac-Van on August 18, 2008 for the wet stamped engineering drawings. An early award was required in order to obtain the wet stamped engineering drawings, which Boulder City and CivilWorks required to 
complete approval of the site plans and the septic drawings. The actual building delivery was in June 2010. PacVan provided the steps to the backdoor and a front door handicap ramp at no cost.

Inspection Fees, Bonding - Boulder City inspection fees were paid, and a bond was secured.

Other - The STC required temporary power, until either sufficient solar panels were in place or power lines were brought to the site. A used $200636 \mathrm{~kW}$ diesel generator was purchased from Sunstate Equipment in 2010. Two large signs were purchased to inform the public of the purpose of the building a phone number for further information.

\subsection{SUMMARY}

The Solar Technology Center is complete (Exhibit C). Projects have started, and UNLVCER is actively pursuing other projects to be completed on the site. UNLV-CER is also contemplating moving existing solar projects located on campus or other private sites to the STC.

Solar projects will continue through the lease end of May 2042, and maybe beyond. The STC currently shares the approximately 1,110 acres of prime solar-designated land within the Eldorado Valley with the following companies:

Acciona's Nevada Solar One. Completed in June 2007, Nevada Solar One is an environmentally friendly, renewable utility-scale power solution that creates power with near-zero carbon emissions. The 400-acre, 64-megawatt plant harnesses solar energy to power more than 14,000 homes every year. It is the third-largest concentrating solar power plant in the world and the first such plant built in 17 years. Nevada Solar One represents a major renewable-energy success story and has the potential to compete directly with conventional fossil fuel-powered technologies.

Sempra Copper Mountain Solar. Currently the largest photovoltaic solar plant in the United States, the 48-megawatt solar installation was completed December 2010 and now generates enough renewable electricity to power about 14,000 average homes. The site includes nearly 775,000 thin-film photovoltaic solar panels at the 380 -acre desert site. Sempra Generation operates two other power plants in the Eldorado Valley - the 480-megawatt, gas-fired El Dorado Energy and the 10-megawatt El Dorado Solar.

First Solar (NextLight). The Boulder City Solar Project will be a 150 megawatt (MW) solar photovoltaic (PV) generating facility. First Solar is a leading manufacturer of PV solar panels and provider of solar solutions. When fully operational, the 150MW Boulder City Solar Project will generate enough clean solar energy to serve the needs of over 26,000 average homes per year, displacing approximately 123,000 metric tons of carbon dioxide (CO2) per year-the equivalent of taking about 24,000 cars off the road. The Boulder City Solar Project is expected to begin construction in 2011. 


\section{EXHIBIT A}

Solar Technology Center

Business Plan

August 2008 


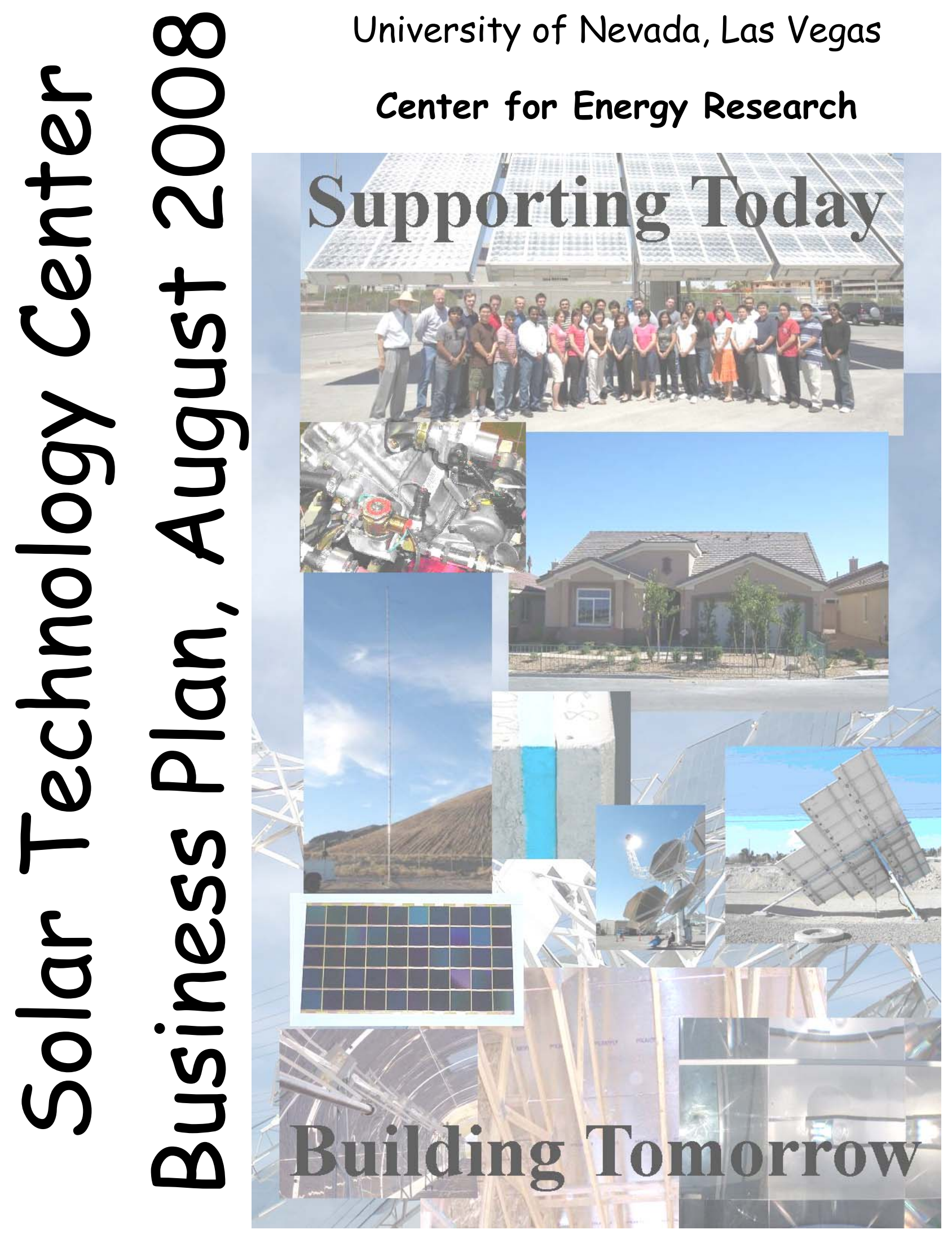




\section{Table of Contents}

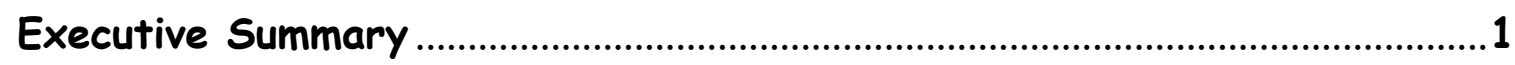

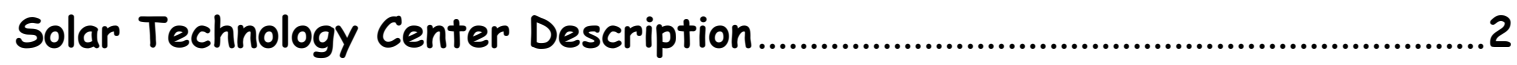

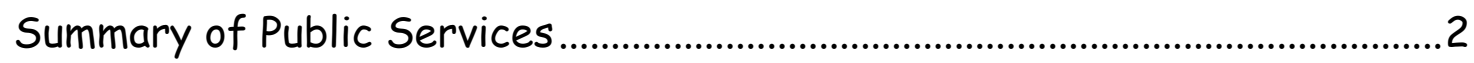

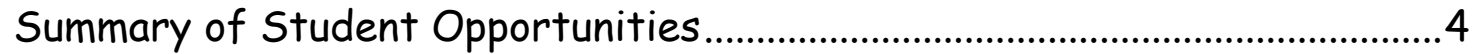

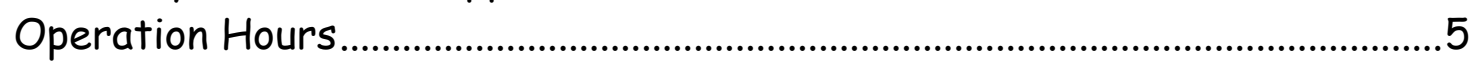

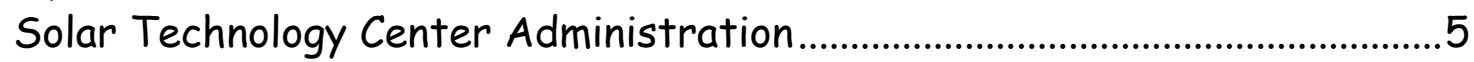

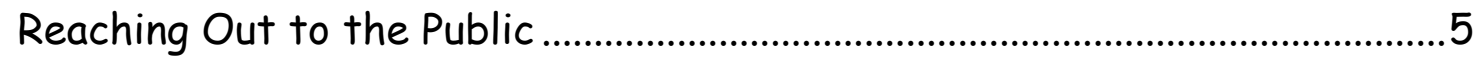

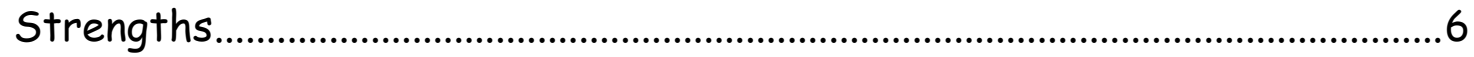

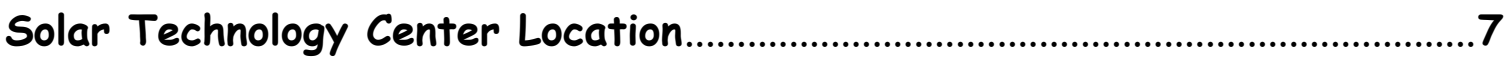

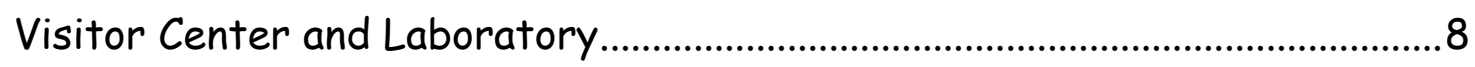

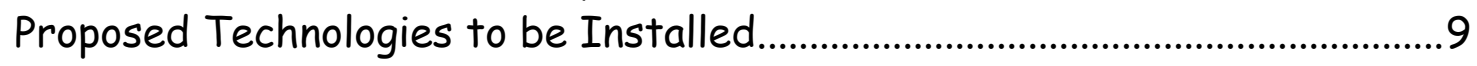

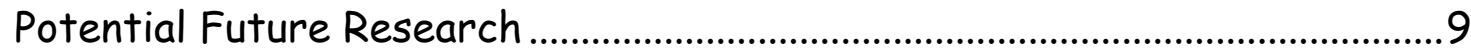

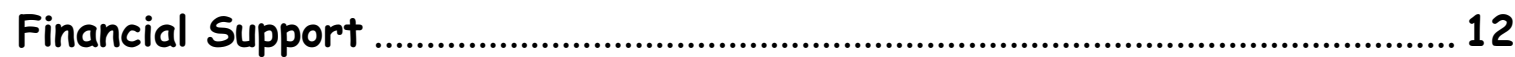

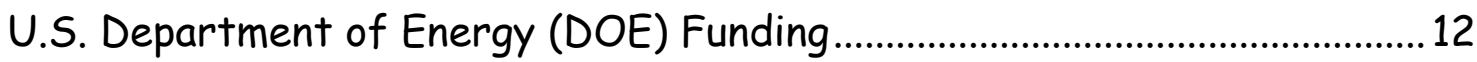

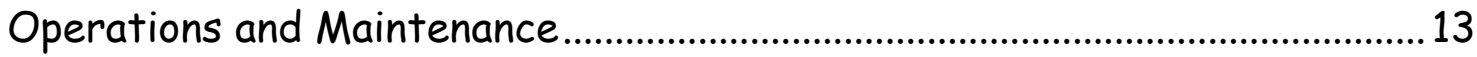

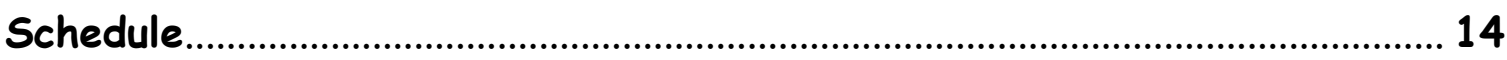

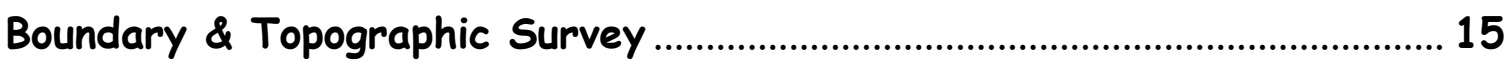

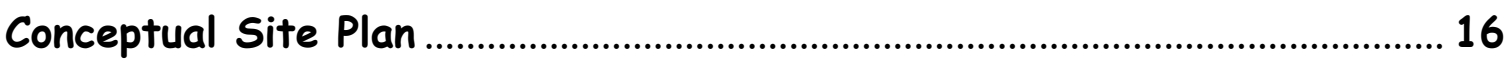

Figures:

Figure 1, Solar Technology Site (STC) ...........................................................

Figure 2, South area of the STC and proposed location of the

Visitor Center and Laboratory.

Figure 3, Approximation of preexisting conduit located west of the main gate and continues to the southwest area the STC property 


\section{Executive Summary}

Renewable energy, and its position in the international energy industry, is developing into a reliable and dependable resource for electricity production and related industrial applications. As non-renewable energy resources decrease, concerns increase for the stability and security for the future. The Solar Technology Center (STC) located in Boulder City, Nevada is a new center that will potentially impact the renewable energy industry. The STC will be a research, development, educational training, and outreach center for renewable energy and conservation.

Through solar energy research and development in point-focus concentrating photovoltaic, linear concentrating photovoltaic, dense photovoltaic array, concentrating dishes, and trough, companies will be able to have a third party evaluation and or test development site for their technologies. This testing will not only include full scale systems, but also the testing of individual components.

Although renewable energy technologies are continuously improving, conservation is an integral part of ensuring that these technologies meet demands. Different types of energy-conserving technologies will be studied, including insulations, surface coatings, textures, roofing, appliances and windows. There are an abundant amount of new efficient energy sources and post consumer products that can be utilized in construction for both residential and commercial buildings. These sources and products could be analyzed at this facility.

The future of renewable energy depends on the workforce that will be created from today's students. It is essential that students are educated and equipped to support this industry through hands-on experience.

The STC will provide this education experience. It will be organized and operated by students, which will offer them opportunities to work with industry partners and prepare them for the future while giving them the tools needed for success.

Reaching out to the community by informing them of new developments in the renewable energy industry is imperative to ensuring that renewable energy is accepted and supported The STC will act as an outreach center for anyone interested in learning about renewable energy and conservation. 


\section{Solar Technology Center Description}

The Solar Technology Center is located in the Boulder City designated 3,000acre Eldorado Valley Energy Zone, approximately 15 miles southwest of downtown Boulder City and fronting on Eldorado Valley Drive. The 33-acre vacant parcel has been leased to the Nevada Test Site Development Corporation (NTSDC) by Boulder City to accommodate a planned facility that will be synergistic with present and planned energy projects in the Zone. The parcel will be developed by the UNLV Research Foundation (UNLVRF). The NTSDC is the economic development arm of the UNLVRF. UNLVRF will be the entity responsible for overseeing the lease and the development project to assure compliance with the lease stipulations established by Boulder City. It is planned that the Center will be operated and maintained by UNLV and/or another education-focused entity as approved by Boulder City.

Land parcels in the Eldorado Valley Energy Zone near the 33-acre lease are committed to the construction and operation of an electrical grid connected solar energy production facility. Other projects supporting renewable and solar technologies are expected to be developed within the energy zone.

The STC will offer services to the community by educating students through hands on experience, and by educating the general public. The STC will be open to anyone interested in the work being done at the center or renewable energy in general. The STC will also act as a clearinghouse and local resource for renewable energy and conservation information.

\section{Summary of Public Services}

During the past several years, the American Government and general public has become increasingly aware of a growing crisis in the availability of energy resources crucial to sustaining the national economy and security. The UNLVRF, acting in coordination with the University of Nevada and Community College System, will develop and operate the STC to support the growth of solar technologies in the Boulder City designated Energy Zone and to provide public information services on solar and other renewable energy resources. Activities at the Center will be limited to those that are consistent with the Boulder City lease and long-terms goals of the City of Boulder City, its citizens and visitors. 
Information that will be available to visitors at the center will include a brief summary on research being conducted, products available to the public, and a list of utility sized plants, both domestic and international. A brief list of some of the general information that is currently available and which will be given to the general public is listed below. This information may be provided through the use of posters, fliers, and the internet. As technology changes or more plants are developed and installed the information will be updated and revised. General descriptions on how the technologies work and their uses will also be presented.

- Solar Power Plants:

- Solar Trough Power Plants

- Nevada Solar One, Boulder City, Nevada-75 MW (Mega Watts)

- SEGS Plants, Mojave Desert, California-354 MW

- Saguaro Trough Plant, Red Rock, Arizona, 1 MW

- Concentrating Solar Power Tower

- Solar One, Kramer Junction, California-1 MW

- Solar Two, Majove Desert, California-10 MW

- Solar Tres, Sevilla, Spain-15 MW

- Solucar, Sevilla, Spain-11 MW

- Concentrating Photovoltaic power plants

- Soleras, Saudi Arabia - 350 Kilo Watts

- Guascor Foton, Talayuela, Spain-10 MW

- Wind farms: ${ }^{1}$

- Washington (9,588 MW installed, $331 \mathrm{MW}$ under construction)

- Texas (3,953 MW installed, 1,357 MW under construction)

- California (2,376 MW installed, 45 MW under construction)

- Iowa (992 MW installed, $383 \mathrm{MW}$ under construction)

- Minnesota (898 MW installed, $453 \mathrm{MW}$ under construction)

- Colorado (630 MW installed, 436 MW under construction)

- Oklahoma (595 MW installed, $95 \mathrm{MW}$ under construction)

- New Mexico (496 MW installed)

o Oregon (438 MW installed, 462 MW under construction)

o New York (390 MW installed, 317 MW under construction)

\footnotetext{
${ }^{1}$ List of the current top ten state total power capacities (MW) provided by the American Wind Energy Association
} 
- Geothermal Plants: ${ }^{2}$

- California has 41 geothermal plants for a total of 2,492 MW

- Nevada has 15 geothermal plant for a total of $397 \mathrm{MW}$

- Utah has 3 geothermal plants for a total of $40 \mathrm{MW}$

- Puna, Hawaii - 35 MW

- Chena Hot Springs, Arkansas - 0.4 MW

- Energy Star appliances:

- Dishwashers

o Lights

o Televisions

o Washers

o Dryers

o Windows

- Green Building Information:

o Post consumer tile, counter tops, carpet, upholstery, insulation, etc. ${ }^{3}$

- Solar panels

- Solar Generations

\section{Summary of Student Opportunities}

To continue furthering the development of renewable energy and conservation it is important that opportunities are given to students. Students are the work force of tomorrow in all industries, including renewable energy. As part of the objective of the STC, industrial research partnerships will be encouraged to offer students opportunities to conduct research that will assist in further developing renewable energy and conservation and related products. Each research project will be catered to the specific industry partner's needs. Projects may consist of system evaluation, performance, reliability, characterization, optimization, design, and/or failure assessment. Each research project will be required to have at least one student participate. It is difficult to know how or what type of research an industry partner will need; therefore the STC will be flexible in its general role as long as there is a potential benefit to the renewable energy industry.

\footnotetext{
${ }^{2}$ List of current geothermal power plants in the United States provided by Geothermal Energy Association

${ }^{3}$ United States Green Building Council
} 


\section{Operation Hours}

Initially there will be no set hours of operation for the STC. The facility will be occupied as needed for the different research projects. Tours will be given at the center by appointment and contact information for scheduling will be posted at the facility and on the STC website.

\section{Solar Technology Center Administration}

University of Nevada, Las Vegas Center for Energy Research (UNLV-CER) will manage all of the tasks for each project that is pursued and ensure that objectives are met and public services are satisfactory. Dr. Robert Boehm is Director of the Center and Distinguished Professor of Mechanical Engineering. His specialties are in the areas of thermal system design and power systems, with particular emphasis on renewable energy concepts. He has focused on renewable energy research with students that address innovative development for cutting edge technology, implementation into the market, and economic benefits to society. The UNLV-CER is a renewable energy center that has goals which are aligned with the STC.

The UNLV-CER has a reputation for on-going program collaborations among industry partners. In the past, students have assisted in developing many solar energy related technologies, such as collaboration on developing and testing solar concentrating photovoltaic and thermal technologies. This includes reliability, performance, design, development, product improvement, assembly in the field, manufacturing, failure testing, component optimization, and electronic design.

The UNLV-CER will perform tours of the facility and related research that are available to organization or individual.

\section{Reaching Out to the Public}

Signage around the facility will provide information on the research work that is being performed at the facility.

A website including all of the STC research projects and contact information will also be developed. 
Tours of the facility, including information about research and commercially available products in renewable energy and conservation, will be conducted. Visitors are expected to be educational institutions, individuals in the community as well as curious individuals driving down Interstate 95.

\section{Strengths}

The STC's greatest strengths focus on educating students and the community through the following offerings:

- A visitor center where the public will have the opportunity to get information on and view different renewable technologies.

- A research center where renewable energy companies can utilize the facility and have access to students to work with them to test prototypes or upgrades to existing and new technologies.

- A research center where students can meet with visitors, give information on emerging technologies, advise on renewable energy applications, monitor and maintain renewable energy equipment, and work with companies on development of new technologies. 


\section{Solar Technology Center Location}

The location of the STC is shown in Figure 1 and outlined in yellow. The center is located on the east side of the Nevada Solar One (NSO), a solar trough power plant in Boulder City, Nevada. The STC is in the shape of a wedge with the longer portion running north-south. This is beneficial for solar energy projects because it minimizes shading. The eastern edge of the property is defined by a natural gas pipeline. Southwest Gas has given permission to install a fence within the gas line easement. Nothing else will be constructed in the easement and Southwest Gas will have twenty-four hour access to the area.

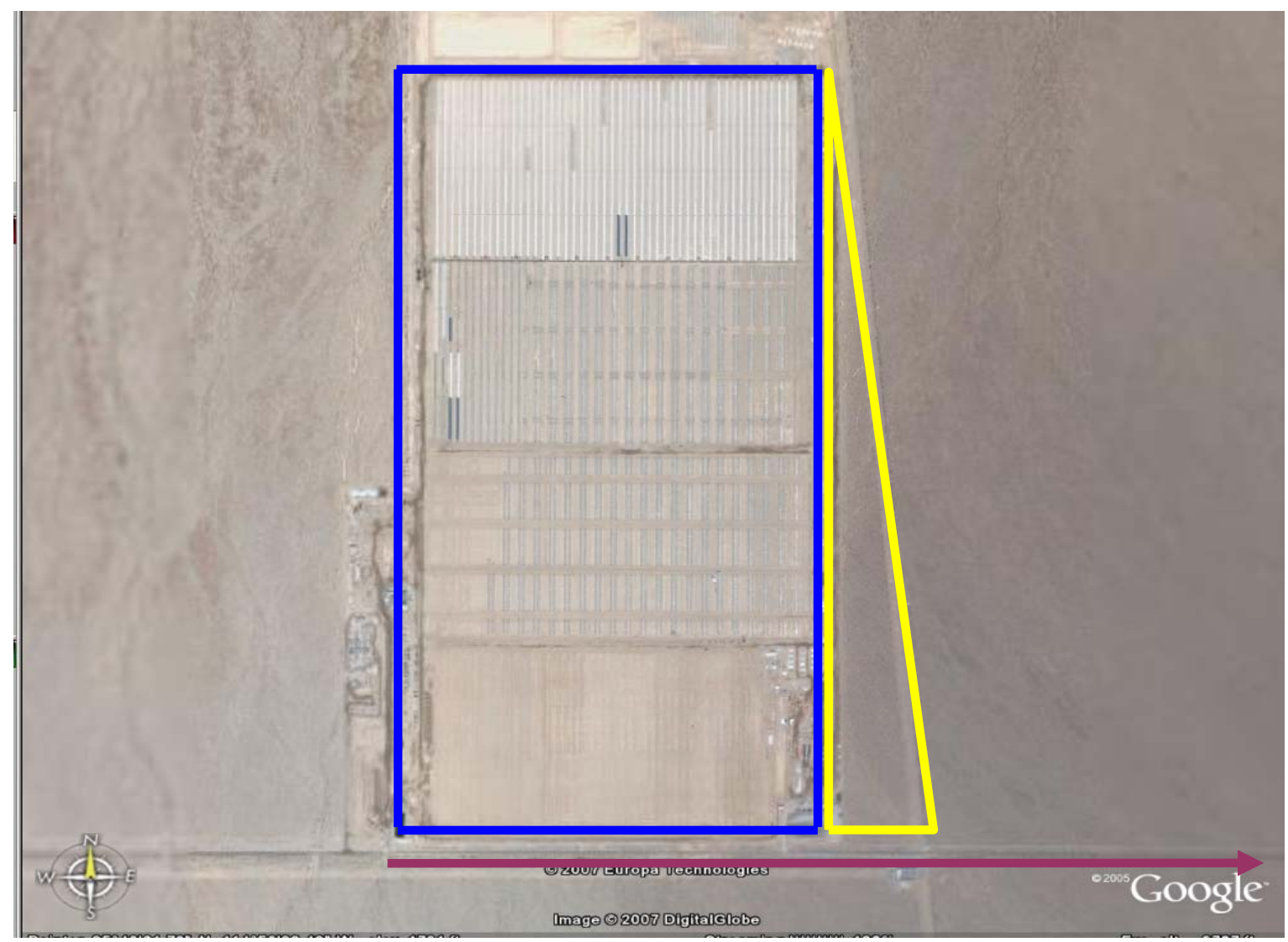

The 33 acre location for STC

Nevada Solar One solar trough site

To US 95 (to Las Vegas and Bolder City)

Figure 1. Solar Technology Site (STC) 


\section{Visitor Center and Laboratory}

This Field Station facility will act both as an educational outreach area for visitors as well as a research laboratory. Figure 2 shows approximate location of Visitor Center and Laboratory building as well as the location of the existing natural gas line.

This facility will have the following properties:

- A modular building with a visitor's center to include looped video on a computer screen, samples of products, a meteorological station; and two or three rooms where visitors can witness on-going experiments being conducted by UNLV graduate students

- Table with hand-outs regarding research projects and renewable energy information

- Storage area for tools

- Identification signage on the outside of the building

- Installed heating and cooling system

- Flexibility for testing equipment in and on top of the building 


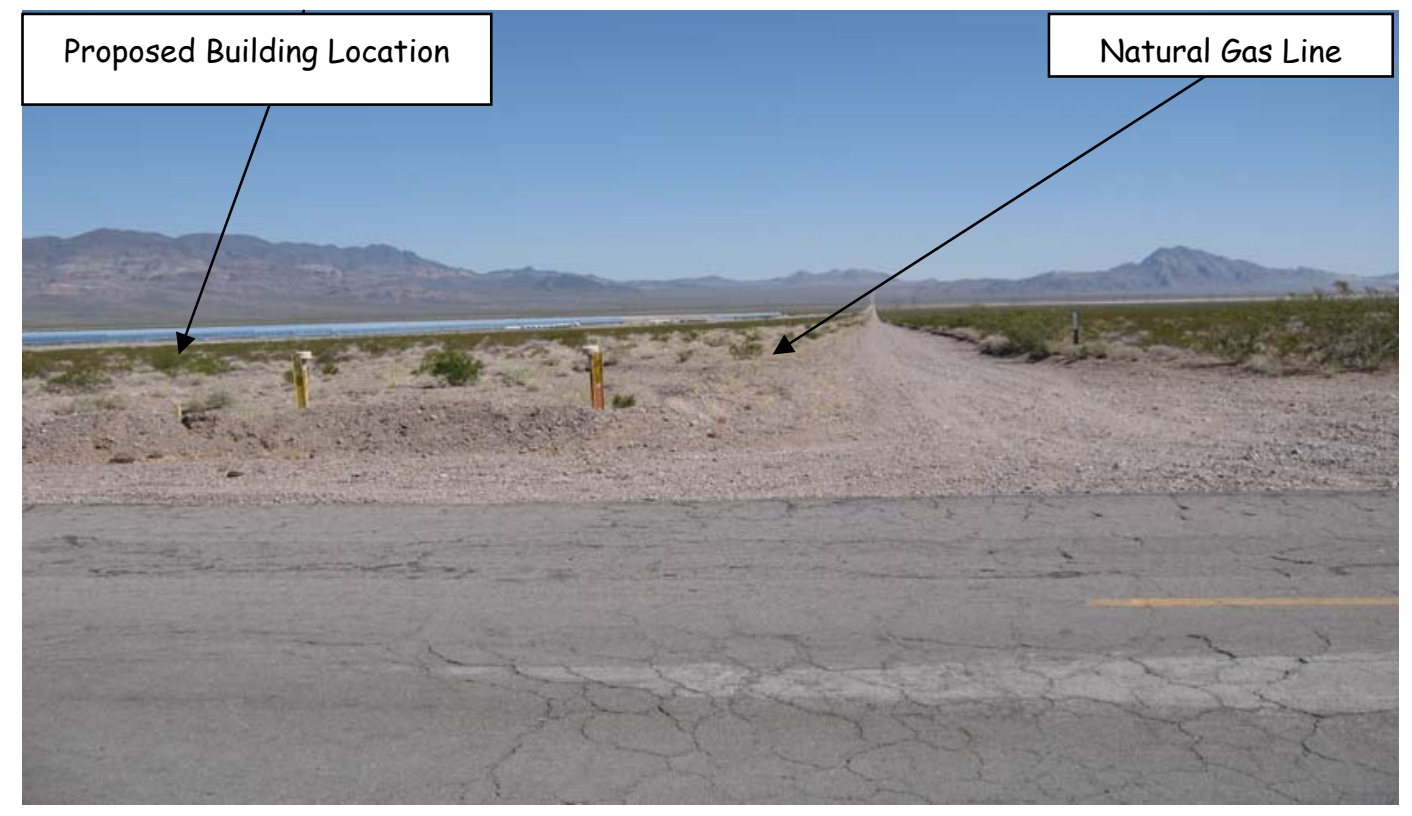

Figure 2. South area of the STC and proposed location of the Visitor Center and Laboratory

\section{Proposed Technologies to be installed}

Multiple companies in the renewable energy field have been approached for testing and evaluation opportunities. Currently Nevada Solar One (NSO), formerly known as Solargenix, is in discussions with UNLV-CER to be one of the first companies at the STC to test and evaluate equipment. One of the experiments under consideration is a test loop. However NSO and other companies will not finalize agreements until such time as the STC is up and operating.

\section{Potential Future Research}

A list of the different technologies that have been discussed for future research is listed below. Due to privacy concerns, the companies that have been contacted are not listed.

- Concentrating Solar Power

o Stirling engines

o Solar trough 
- Concentrating Photovoltaics

o Concentrating PV point focus

o Concentrating PV linear array

o Dense PV array

- Flat plate PV

o Single axis tracking

o Tilted tracking

- Energy Storage

- Tracking and control systems

- Insulation, pre-cast concrete, bio based, soy, phase change, etc.

- Post consumer product testing

The list above does not include all of the research projects that are possible at the STC. It is a sample of the types of opportunities that could be pursued.

Some objectives that can be achieved at the STC are listed below:

- Determine long term performance

- Determine degradation as a function of time

- Determine reliability

- Verify new designs

- Determine an estimate of the annual energy generated (in applicable situations)

- Determine wind loading and bending stresses

- Analyzing mounting methods which will survive the operating environment and maintain the required optical alignment 
- Verify and define stresses at critical design point wind loads

- Mechanical component optimization

- Develop product design specifications

- Tolerance design of optimum quality in preparation for large scale manufacturing

- Stress component study

- Failure mode effect analysis 


\section{Financial Support}

The support for the facility and students will initially be from research projects. This support may come from either industry partners or research grants. Considering that research and development activities can vary over long periods and that there may be a need to secure other forms of financial support, the potential for renewable energy generation at this site will be evaluated. According to the current lease agreement in Section Six, Part A, Boulder City is entitled to all of the benefits associated with any generation including green energy credits and emission offsets. It is hoped that in the future an amendment can be developed so that the STC can benefit from energy production at the site to provide continuing financial support that will contribute to making the center self supporting.

Nevada Solar One (NSO) is in discussion with UNLV-CER to assist the STC with utilities. NSO has a fiber optic communications tap available west of the NSO main gate with a pre-existing conduit from this location to the south west area of the STC property (see Figure 3). From this south west point the STC will have to install conduit and feed the communications lines to the visitor center and laboratory. Electricity and water can be provided by the NSO facility by bringing these to the NSO east fence line. At this point it will be the STC's responsibility to bring the water and electricity to the needed locations (see Figure 3). Should the NSO not provide access to utilities, other opportunities will be explored and pursued.

\section{U.S. Department of Energy (DOE) Funding}

The STC Project is being managed by UNLVRF. A grant provided by DOE for the feasibility study, National Environmental Policy Act (NEPA Environmental Assessment), surveying, design, civil engineering, and the modular building design in the amount of $\$ 263,335$ has been received by UNLVRF to initiate the project development and to meet the lease requirements of Boulder City.

Additional funding in the amount of $\$ 480,724$ will be allocated for site construction, including fencing, parking lot, septic, and installation of the modular building. If sufficient funding remains, a sign, meteorological station, and other research equipment will be secured 


\section{Operation and Maintenance}

The operation, site and facility maintenance, personnel costs and research activities will be provided by UNLV throughout the lease period.

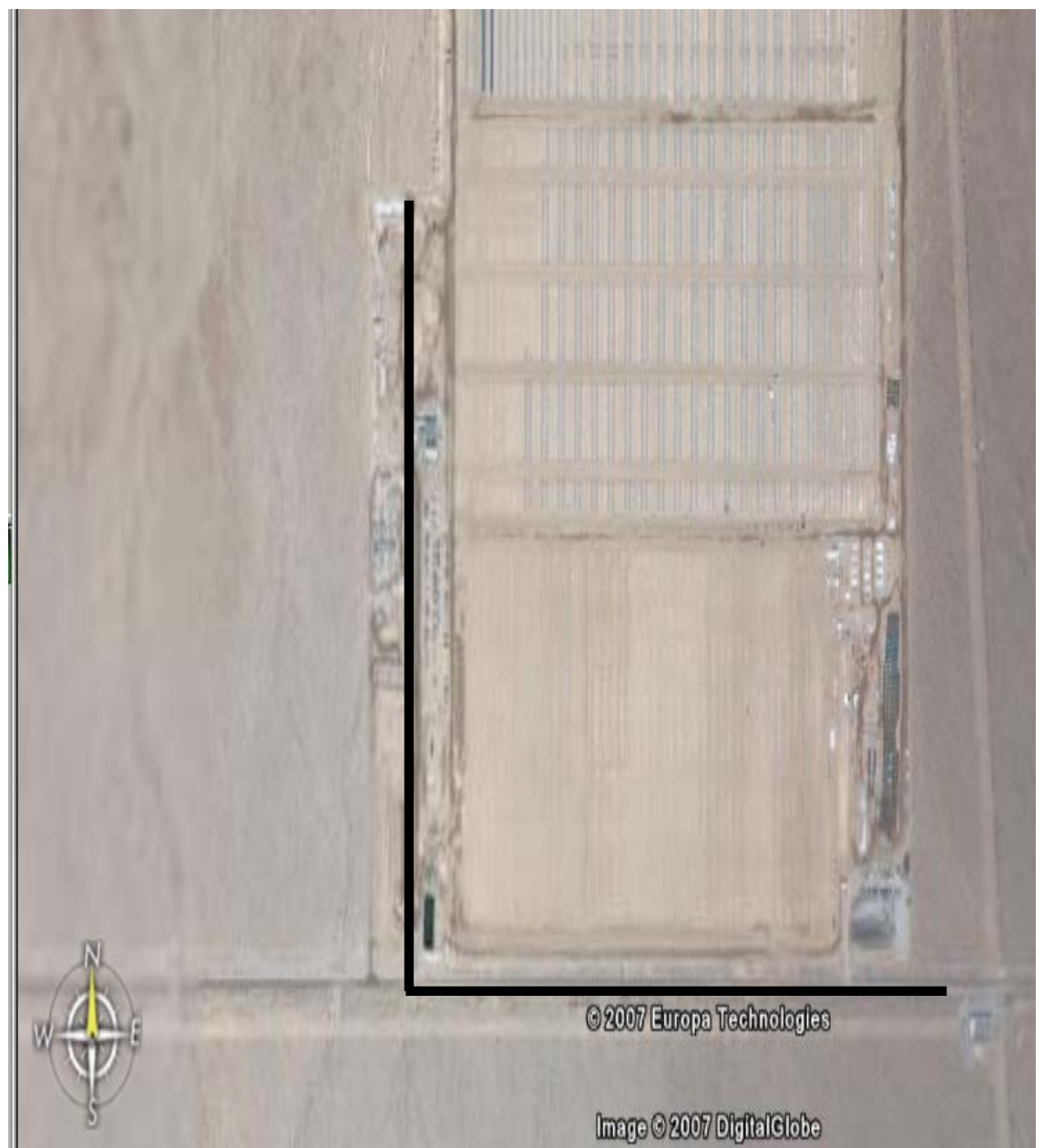

Figure 3. Approximation of preexisting conduit located west of the main gate and continues to the southwest area the STC property. 


\section{Schedule}

The engineering tasks have commenced and will be completed and submitted to Boulder City as required in the Lease by February 28, 2009. The NEPA Study has begun and, if a Finding of no Significant Impact (FONSI) is determined the study will be completed and approved by DOE before the end of calendar year 2008. A previous study was conducted by the Bureau of Land Management (BLM) at the time the land was transferred to Boulder City in 1994 with a finding of no significant impact. Casual field observation finds little change in the site since 1994 and therefore, based upon this observation; it is believed that a FONSI will be issued for the project.

Upon the approval of the NEPA Study, construction on the site will commence with a projected completion date of July 1, 2009. 


\section{Boundary \& Topographic Survey}

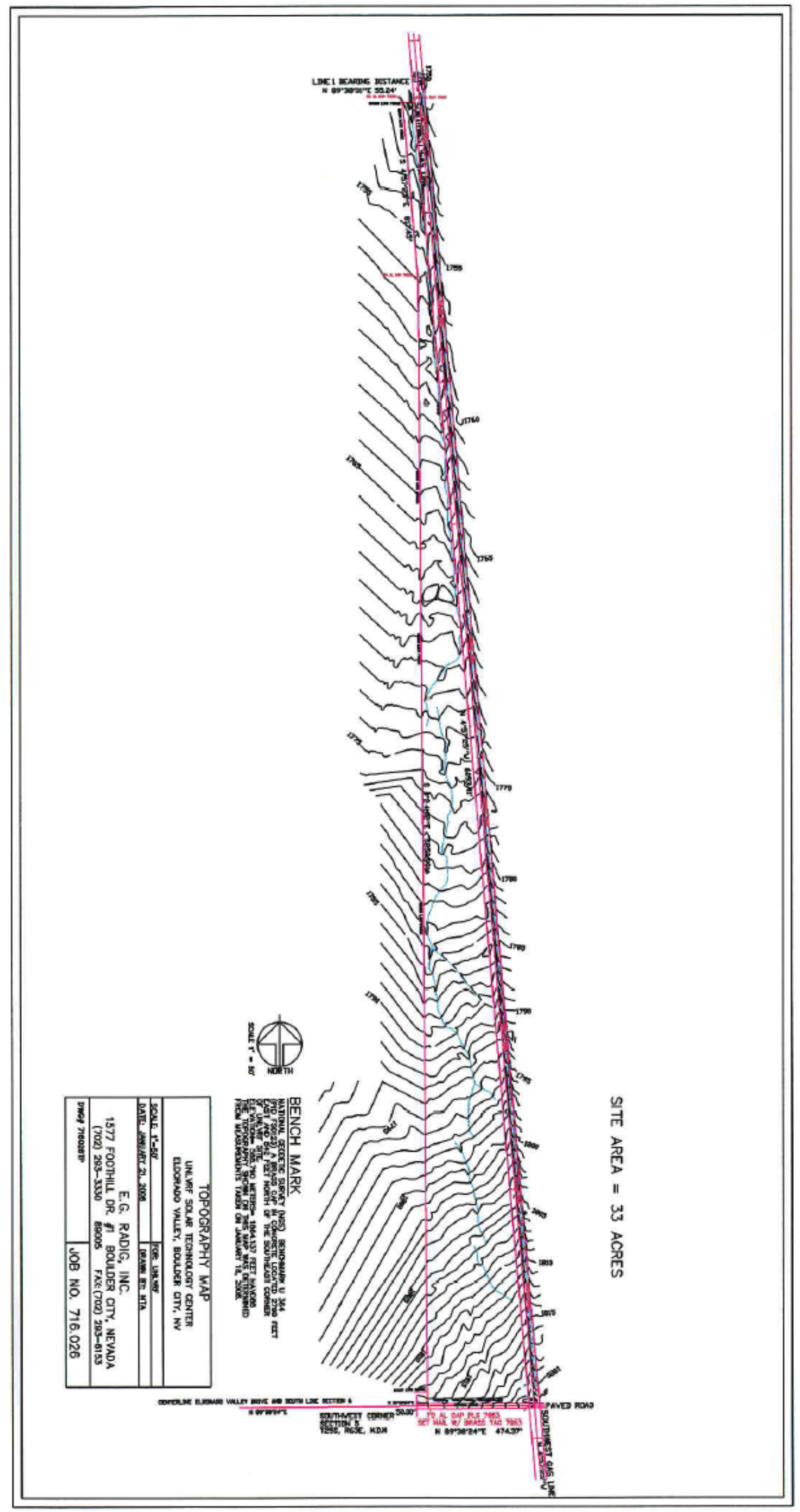




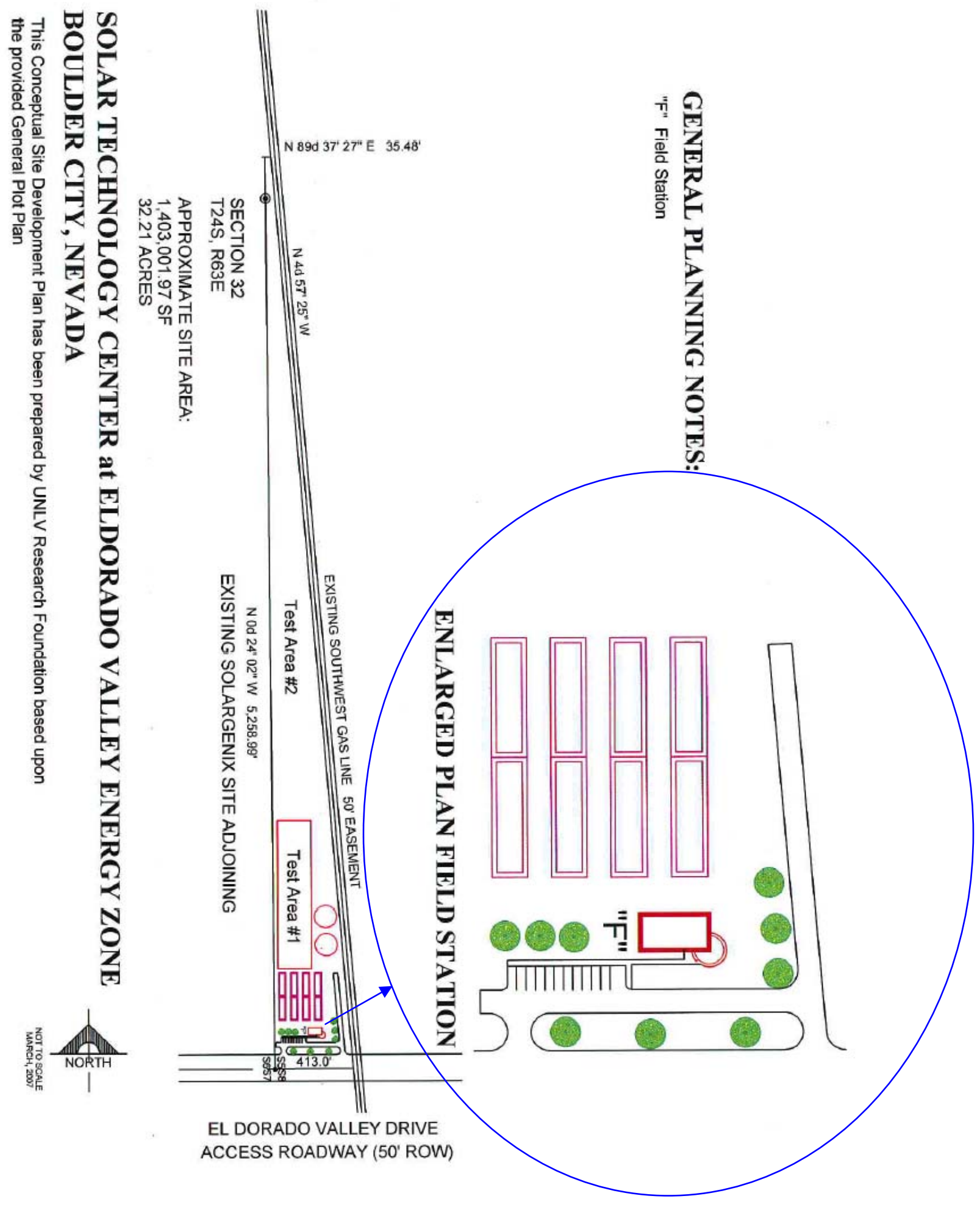




\section{EXHIBIT B}

Solar Technology Center

Site Plan 


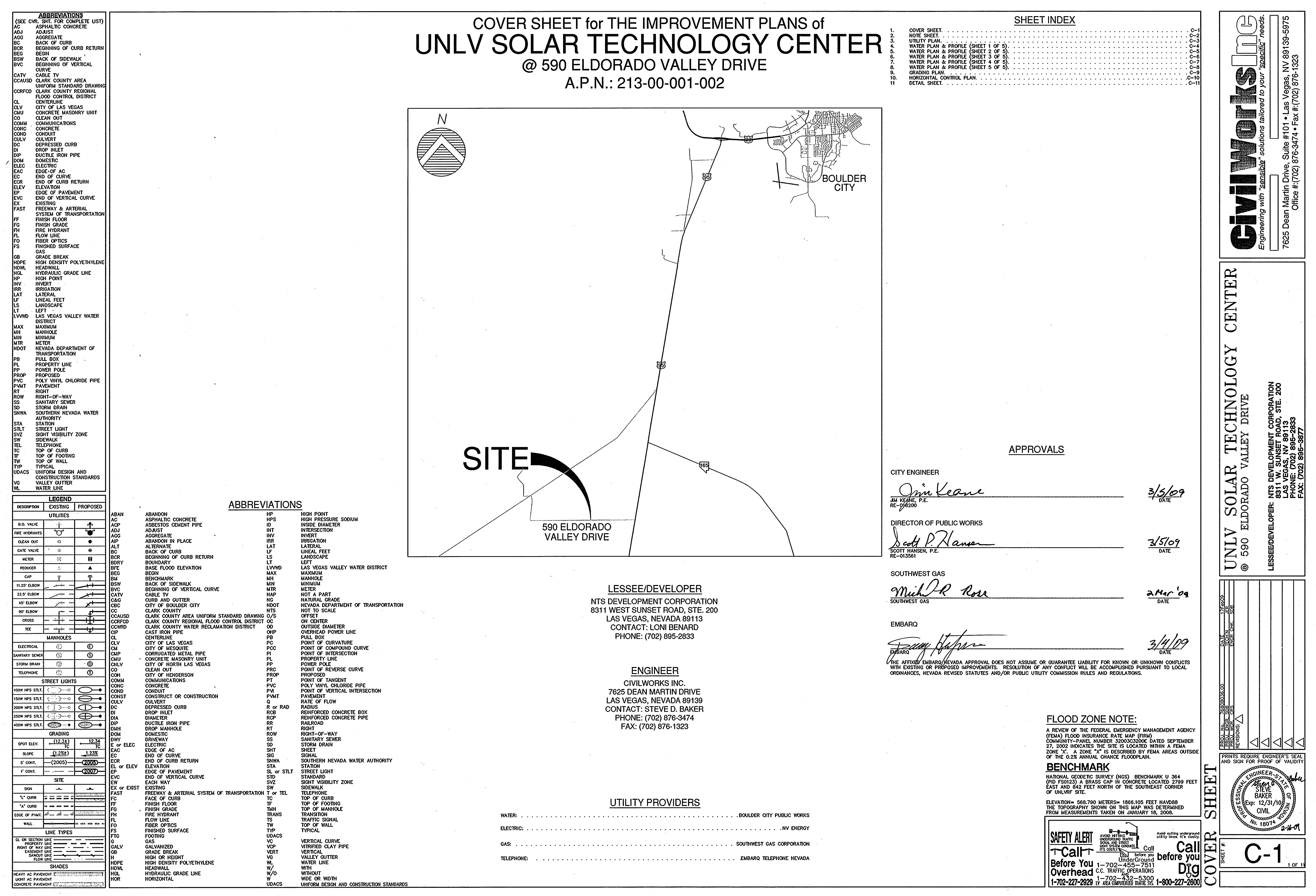




\section{EXHIBIT C}

Solar Technology Center

Pictures 


\section{SOLAR TECHNOLOGY CENTER}

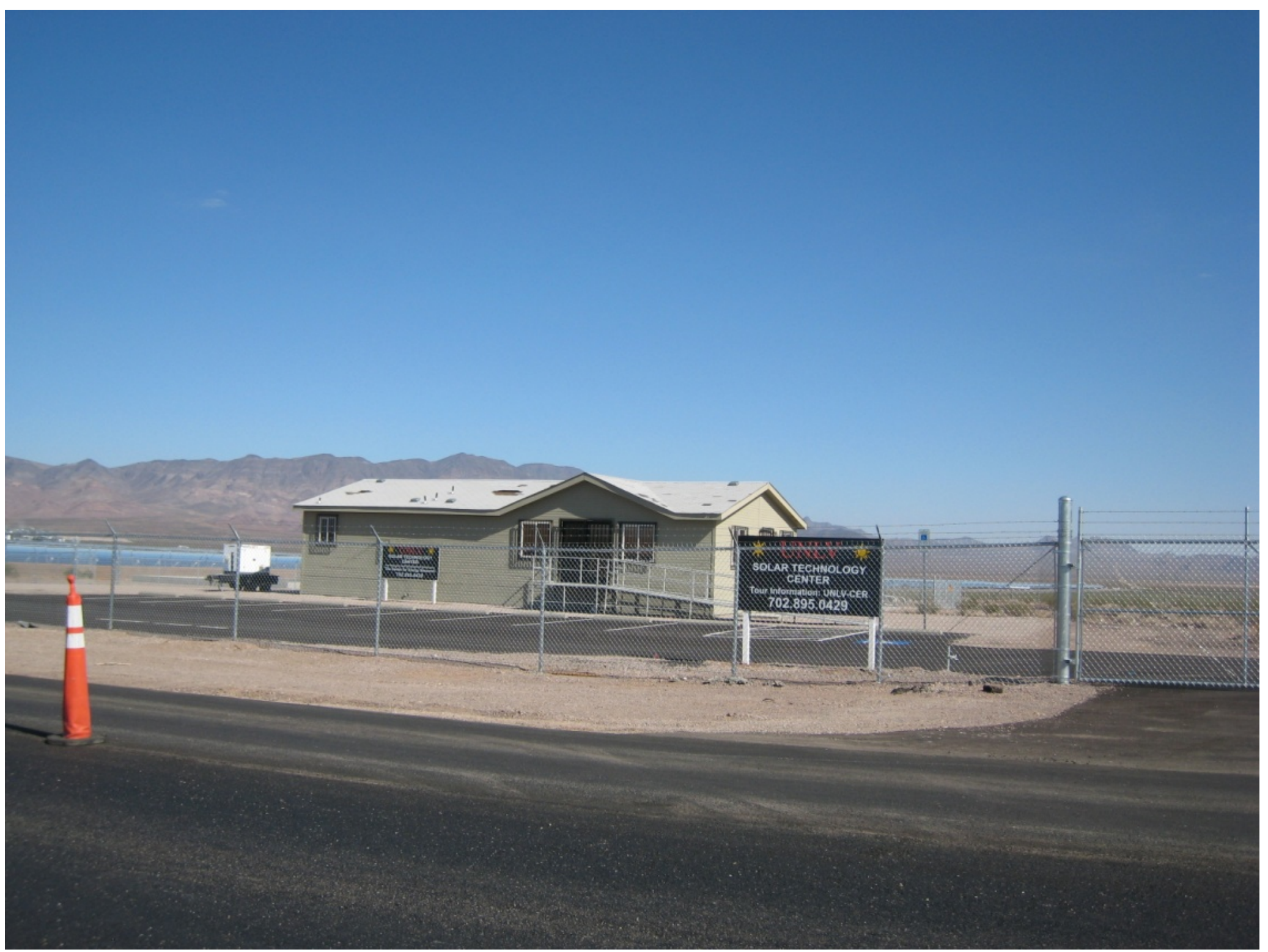

Picture 1: Solar Technology Center south of Eldorado Valley Drive. To the left of the building are the Acciona Solar One solar fields 


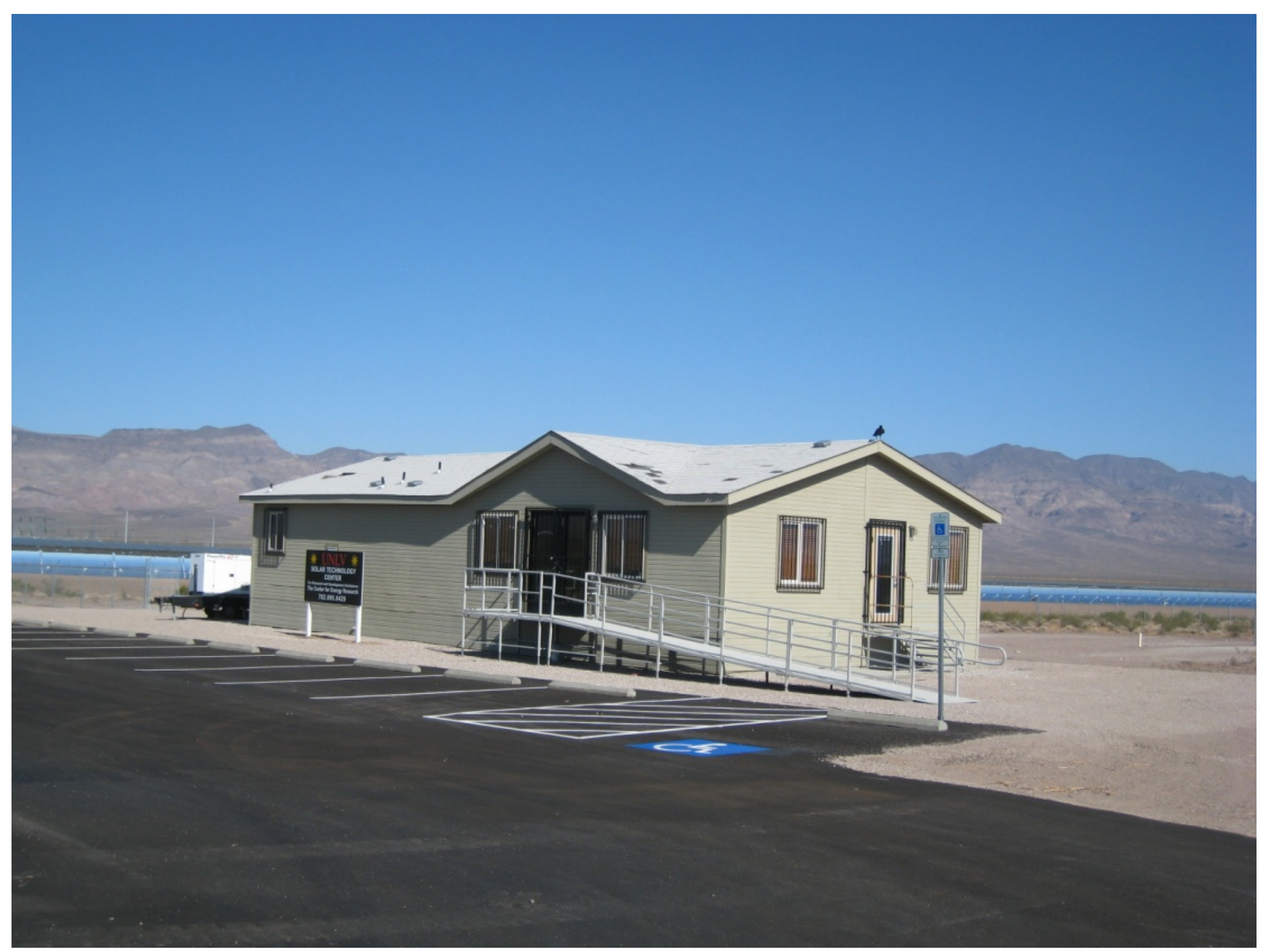

Picture 2. The Solar Technology Center. 


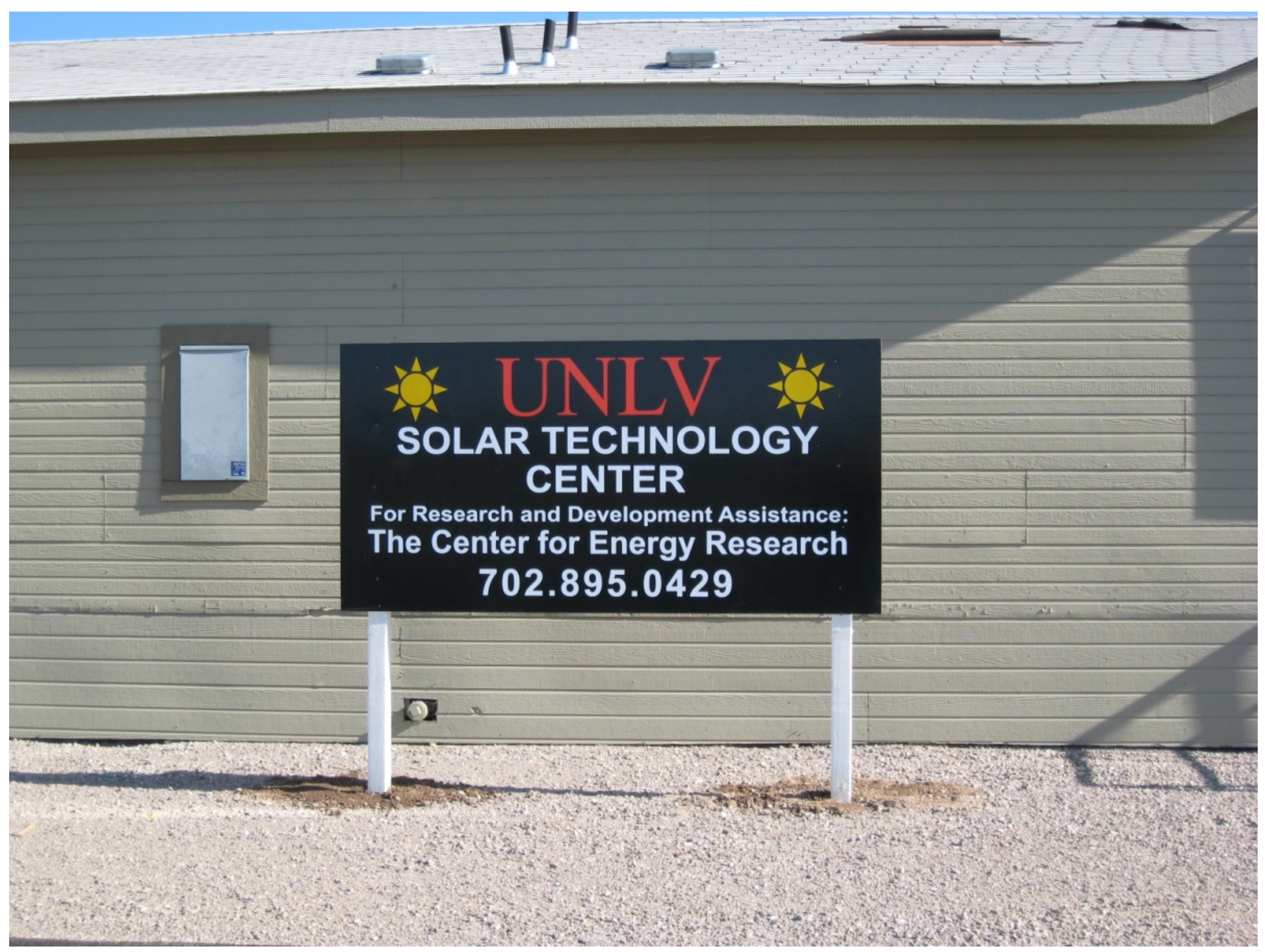

Picture 3. One of the two signs to assist the public with obtaining further information about the site. 


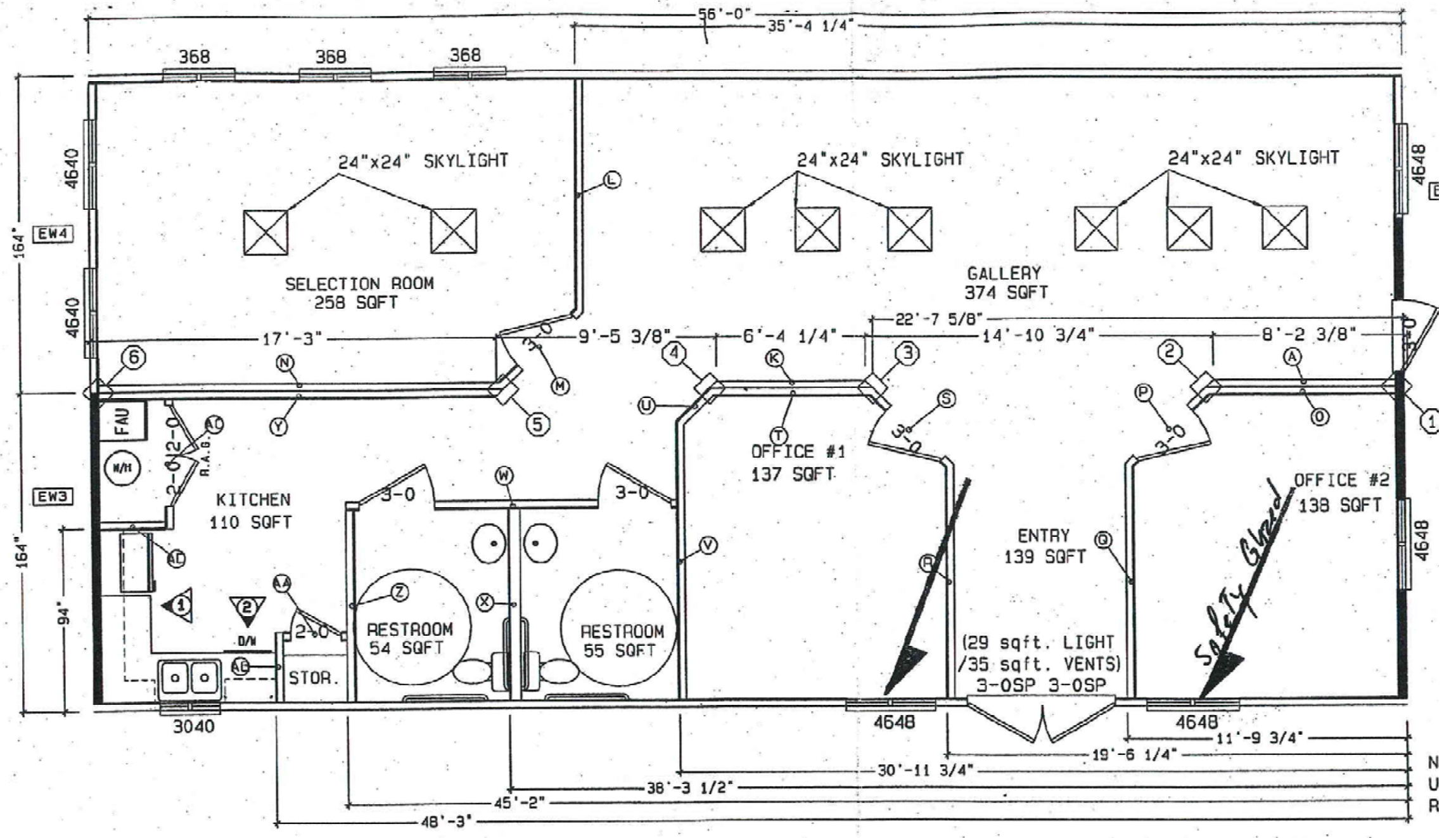

Picture 4. The Solar Technology Floor Plan. 


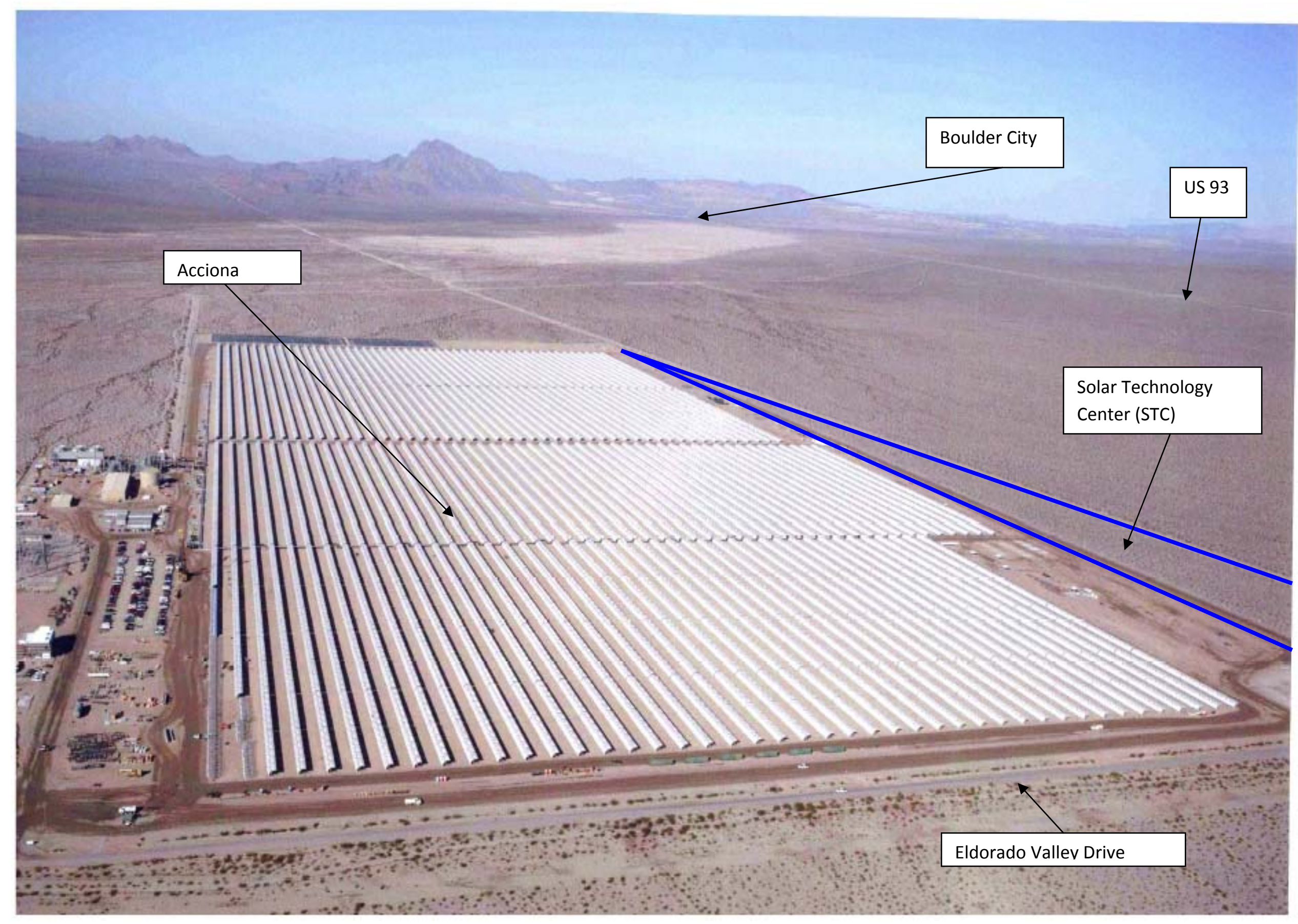

Picture 5. Aerial view of Eldorado Valley Drive. 